\title{
Temas hispanos en las revistas de Lajos Kassák
}

\section{Hispanic Motifs in Journals of Lajos Kassák}

\author{
Eszter Katona \\ Universidad de Szeged, Departamento de Estudios Hispánicos, \\ Facultad de Letras, Hungría. \\ katonaeszter@gmail.com
}

\section{Resumen}

El nombre de Lajos Kassák (1887-1967), el representante más importante del vanguardismo húngaro, no es muy conocido entre el público hispanohablante debido sobre todo a que sus obras literarias, por falta de traducciones, no llegaron a los lectores españoles e hispanoamericanos. Sin embargo, tanto en la obra propia de Kassák como en las revistas fundadas por él muchas veces aparecen diferentes temas hispanos. El presente artículo examina los temas y personalidades españoles e hispanoamericanos que recibieron atención y publicidad en las cinco revistas - A Tett, Ma, Munka, Dokumentum y Kortárs-fundadas por Lajos Kassák.

Palabras clave: Lajos Kassák, revistas de la vanguardia húngara, España, temas y personalidades hispanos.

\section{Abstract}

The name of Lajos Kassák (1887-1967), the greatest figure of the Hungarian avant-garde is not well known to the Spanish-speaking public, mainly because the lack of translations of his literary works, that consequently did not reach Spanish and Hispanic American readers. However, both in Kassák's own work and in the journals he founded, many different Hispanic themes do appear. The present article examines the Spanish and Hispanic American motifs and personalities receiving attention and publicity in the five journals - A Tett, Ma, Munka, Dokumentum y Kortárs- founded by Lajos Kassák.

Keywords: Lajos Kassák, Hungarian Avant-garde Journals, Spain, Hispanic Themes and Personalities. 


\section{Introducción}

Lajos Kassák, poeta, escritor, pintor y diseñador, fue el mejor representante del grupo de artistas vanguardistas húngaros. Junto a su obra literaria, Kassák fundó también cinco revistas literarias y culturales: en 1915, A Tett, una revista «activista», prohibida en 1917 por su espíritu antibélico; en 1916, la revista $M a$, que seguiría publicando incluso en Viena, durante la emigración de su fundador; en 1926, la revista Dokumentum, de muy breve vida, que se publicó hasta 1927; en 1928, la revista Munka, la publicación más duradera (1928-1939), y por último, en 1945, la revista Kortárs, que cesó en 1948.

En 2017, para conmemorar el doble aniversario de Kassák -tanto el de su nacimiento (1887) como el de su muerte (1967) - realizamos una investigación sobre el artista, desarrollada por otras líneas paralelas. Por un lado, concentramos nuestra atención en su recepción española (Katona, "Kassák Lajos és a magyar avantgárd”) y, por otro lado, repasamos también la aparición de España y de temas hispanos tanto en la obra propia del escritor vanguardista (Katona, "España y temas hispanos en la obra”) como en las cinco publicaciones periódicas fundadas por él. El presente artículo pretende resumir los resultados de esta última línea de nuestra investigación, pues examina cómo aparece España y qué temas relativos a las personalidades y a la cultura hispanas reciben atención en las revistas de perfil literario y sociocultural de Kassák.

Los lectores españoles se encontraron por primera vez con el nombre de Lajos Kassák en la década de los veinte, gracias a los artículos de Andrés Révész. ${ }^{1}$ Sin embargo, la obra literaria del artista húngaro no llegó a los lectores hispanohablantes por falta de traducciones literarias, ${ }^{2}$ por lo que Kassák es más bien conocido en España y en Hispanoamérica como pintor y diseñador. ${ }^{3}$ Tampoco las noticias sobre sus revistas despertaron mucho interés entre los lectores españoles y latinoamericanos que conocieron solamente los títulos de estas -traducidos al castellano como La Acción [A Tett], Hoy [Ma], Trabajo [Munka], Documento [Dokumentum], Contemporáneo [Kortárs]- en las breves notas biográficas sobre el artista vanguardista. Cabe recordar, sin embargo, que la actividad multilateral de Lajos Kassák queda reflejada en gran parte en las revistas fundadas por él (Galambos 1). Así, el objetivo de nuestra investigación fue averiguar qué temas y personalidades de la cultura española e hispanoamericana aparecieron y recibieron publicidad en las páginas de las revistas arriba mencionadas.

1 Andrés Révész (1896-1970), periodista húngaro que vivió en España y trabajó en la redacción de más periódicos y revistas españolas. Encontramos reseñas de Révész sobre Kassák en Cosmópolis y en La Gaceta Literaria ("El movimiento literario en Hungría"; "Kassák y su Dokumentum"; "Kassák Lajos: Egy embre élete").

2 Solo muy pocas obras literarias de Kassák fueron traducidas al español: cabe destacar la selección poética de Éva Tóth (200-205), pero, hasta el momento, ninguna de sus novelas ha sido traducida en su integridad.

3 Entre las investigaciones españolas sobre Kassák y su círculo, cabe destacar el trabajo de Manuel Sánchez Oms (2008). Se organizaron en España dos exposiciones, ambas en Valencia. La primera, en 1999, en el IVAM, con el título Lajos Kassák y la vanguardia húngara (VV. AA., 1999), y la segunda, en 2009, en el MuVIM, dedicada a la presentación de El cartel comercial moderno de Hungría 1924-1942 (VV. AA., 2009). 


\section{La revista $A$ Tett [La Acción]}

La primera revista fundada por Lajos Kassák fue A Tett [La Acción], publicada en 1915-1916. Esta significó la inauguración de la vanguardia húngara, y su ejemplo fue la revista Die Aktion, órgano destacado del activismo alemán. En el círculo de A Tett se unieron los representantes más importantes del activismo húngaro y europeo. ${ }^{4}$ Kassák y sus colaboradores no optaron por ninguno de los ismos de dicho periodo, y se declararon cosmopolitas y antibélicos. El segundo número de A Tett fue prohibido por agitación política y el último por su antibelicismo.

Repasados los diecisiete números ${ }^{5}$ de la primera revista de Kassák, encontramos una sola alusión a la cultura hispana, concretamente una reseña de temática teatral. En la sección de "Krónika” "“Crónica”] del segundo número de 1915 (15 de noviembre), podemos leer la crítica de Zoltán Haraszti sobre el drama El alcalde de Zalamea (1636) de Calderón de la Barca, estrenado en el Teatro Nacional de Budapest: "Calderón fue un hombre fenomenal y un poeta grandioso [...] y solo le faltaba un paso hasta la genialidad" (Haraszti 35) -escribe el crítico-. Esta obra de Calderón había sido estrenada en Hungría ya varias veces ${ }^{6}$ antes de 1915 , pero el periodista destaca la actualidad de la obra por la guerra mundial: "la obra parece muy actual porque aparece en ella la vida de los soldados. Uno de sus protagonistas es un soldado, un anciano gotoso y regañón" (35). Aunque el reseñador elogia al dramaturgo, la traducción del drama al húngaro recibe más bien una fuerte crítica: "La traducción de Vilmos Győry [...] es más antiguada que el drama mismo. Es tan floja que ya duele escucharla [...] y los baratos troqueos hieren los oídos" (35). La opinión negativa de Haraszti llega a tal punto que el crítico le pone al traductor -que fue, por otro lado, el primero que hizo la traducción íntegra de El Quijote al húngaro- el sello menospreciador del diletantismo.

\section{La revista $M a[H o y]$}

Después de la prohibición de A Tett, Kassák fundó su segunda revista cultural -aún estando en 1916- con el título Ma [Hoy]. El fracaso de la Revolución de los Crisantemos, ${ }^{7}$ en 1919, obligó a Kassák y a muchos otros intelectuales a emigrar, pero el artista de vanguardia siguió editando Ma. Durante los años del exilio, desde 1920 hasta su cese,

4 Por ejemplo: Libero Altomare, Guillaume Apollinaire, Mihail Arcibasev, Georges Duhamel, Paul Fort, Vaszilij Kandinszkij, Filippo Tommaso Marinetti, Ludwig Rubiner, Bernard Shaw, Émile Verbaeren.

5 El su primer año, la revista cuenta con doce números, mientras que el segundo año ve aparecer solo cinco.

6 Según Haraszti, en el Teatro Nacional "se pusieron ya seis veces esta pieza"; sin embargo, en la base de datos del OSZMI (Museo e Instituto Nacional de Estudios de Teatro de Hungría) encontramos solamente noticias sobre tres estrenos entre 1842 y 1915: en 1842, en 1883 y en 1902. Haraszti, según los datos del OSZMI, vio la dirección de Jenő Ivánfi, cuyo estreno fue el 27 de octubre de 1915.

7 Revolución húngara, entre 28 y 31 de octubre de 1918, motivada por el hartazgo de la Primera Guerra Mundial y por el deseo de reformas políticas, económicas y sociales. El alzamiento recibió su nombre de la flor (crisantemo) que los soldados y los civiles llevaron en sus sombreros. 
la revista de perfil artístico y social se editó en Viena. Su edición duró hasta el cuarto número, el 15 de junio de 1925. Ma -sobre todo en su periódico vienés- fue uno de los órganos internacionales de las más modernas tendencias literarias y de las bellas artes. En sus páginas se encontraron los representantes más importantes de todos los ismos de los años veinte, y ofreció un amplio abanico de las artes de diferentes países. Así, en los números de 1921, 1922 y 1923 aparecieron algunas obras de artistas españoles e hispanoamericanos que presentaremos en adelante.

En dos números de la revista Ma encontramos obras de autoría española e hispanoamericana. En el no 8 ( $1^{\circ}$ de agosto de 1921) se editó un poema de Humberto Rivas Panedas, representante del ultraísmo ${ }^{8}$ nacido en España en $1918,{ }^{9}$ para expresar una posición en contra del modernismo dariano. Los ultraístas trabajaban bajo la influencia de los futuristas italianos, aunque se diferenciaban de la escuela de Marinetti por definirse exclusivamente como escuela literaria y, sobre todo, poética; sin embargo, en sus publicaciones aparecieron también las reproducciones de obras de bellas artes de los vanguardistas. Los ultraístas se concentraron alrededor del círculo de la revista Grecia (1918-1920), editada en Sevilla, ${ }^{10}$ y alrededor del grupo intelectual de la revista Ultra $^{11}$ (1921-1922) de Madrid. Estas dos revistas fueron los foros más importantes de la transición del modernismo a la vanguardia (Menczel 8).

Junto con Humberto Rivas, muchos poetas españoles adhirieron al movimiento ultraísta, como por ejemplo, Gerardo Diego, Pedro Garfias, Juan Larrea, Ernesto López-Parra, Lucía Sánchez Saornil ${ }^{12}$ y Guillermo de Torre. La denominación ultra quería expresar el deseo de superar la estética anterior, sin embargo, el grupo no creó un programa artístico bien definido sino que realizó más bien una mezcla de los ismos, con huellas futuristas, dadaístas y creacionistas (Ródenas de Moya 27-8). Jorge Luis Borges, durante su visita en España, entró en contacto con este ismo español y, gracias a él, el ultraísmo se aclimató también en Argentina. Borges escribió un ensayo que sintetizaba los rasgos peculiares de la poesía ultraísta, y que fue publicado en el no 151 (diciembre de 1921) de Nosotros, importante revista cultural bonaerense:

1. Reducción de la lírica a su elemento primordial: la metáfora.

2. Tachadura de las frases medianeras, los nexos y los adjetivos inútiles.

8 Además, después de su establecimiento en México, en 1923, fue también miembro del grupo del estridentismo.

9 Fue la fecha de la aparición del primer manifiesto del ultraísmo firmado por Xavier Bóveda, César A. Comet, Guillermo de Torre, Pedro Garfias y Humberto Rivas Panedas. El líder del ultraísmo -y uno de los ideólogos más destacados de la vanguardia española- fue Rafael Cansinos-Asséns, que organizó su círculo literario en el madrileño Café Colonial (Menczel 8-9).

10 Fue fundada y dirigida por Isaac del Vando Villar. Su redactor jefe fue Adriano del Valle.

11 Cabe mencionar que no solo Kassák prestó atención a Ultra sino también la revista sevillana dio publicidad al primer número de 1922 de $M a$, la revista más notable del vanguardismo húngaro (Ultra, nº 22, 15 de enero de 1922, pág. 4), destacando los nombres de Lajos Kassák, Erzsi Újvari, Róbert Reiter, Sándor Barta, Andor Simon, Ervin Enders, László Remenyik, Lajos Kudlák y Ernő Kállai. Tenemos que corregir un detalle de la reseña de la revista española: el lugar de la publicación, en 1922, no fue Budapest sino Viena ya que Ma fue editada entre 1920 y 1925 en la capital austríaca.

12 La poeta publicó sus obras generalmente bajo el seudónimo masculino Luciano de San-Saor. 
3. Abolición de los trebejos ornamentales, ${ }^{13}$ el confesionalismo, la circunstanciación, las prédicas y la nebulosidad rebuscada.

4. Síntesis de dos o más imágenes en una que ensancha de ese modo su facultad de sugerencia.

5. Imágenes y metáforas chocantes, ilógicas, donde destacan el mundo del cine, del deporte, del adelanto técnico. [...]

6. Tendencia a establecer una disposición tipográfica nueva de las palabras del poema, pretendiendo de ese modo hacer ver una fusión de la plástica y la poesía.

7. Neologismos, tecnicismos y palabras esdrújulas.

8. Eliminación de la rima. (Borges, "Ultraísmo" 466).

Humberto Rivas pertenecía, pues, al movimiento ultraísta, y la revista Ma publicó la traducción de su poema con el título "Océano" en el no 8 de $1921 .{ }^{14}$ Surge la pregunta: ¿por qué eligió Kassák justamente este poema de Rivas y no una obra de otro ultraísta español, por ejemplo, de Gerardo Diego o Guillermo de Torre?

Parece probable que, con la colaboración de Tadeusz Peiper, llegara a Kassák el $\mathrm{n}^{\circ} 12$ de la revista Ultra (30 de mayo de 1921), que contenía el poema de Rivas (Rivas Panedas, 1921a: 3). El polaco Peiper -la figura más destacada del grupo literario de la Awangarda krakowska - pasó cinco años en España entre 1915 y 1920, y allí hizo amistad, mediante su compatriota, el pintor Władysław Jahl, con los poetas de la vanguardia española, con los que mantuvo contacto también después de volver a Polonia. ${ }^{15}$ Jahl participó también en la redacción de Ultra, y más obras suyas, sobre todo xilografías, fueron reproducidas - muchas de ellas en las portadas $-{ }^{16}$ por la revista madrileña. Antes de volver a su patria, Peiper pasó por Viena, y así probablemente llamase la atención de Kassák a Ultra y a los poemas ultraístas. Peiper mismo tradujo el poema de Rivas al polaco y lo publicó en mayo de 1921 -antes de la traducción al húngaroen Formiści, la revista de los formalistas de Cracovia (Rivas Panedas, "Océano"). La relación entre la versión polaca y la húngara se observa también en un hecho formal: en ambas traducciones faltan las tres líneas dedicatorias ${ }^{17}$ que escribió Rivas a Jorge Luis Borges. Entonces, podríamos preguntar: ¿por qué eligió justamente el poema de Rivas? Probablemente porque Peiper quisiera expresar su homenaje tanto a Humberto

13 La expresión "trebejos ornamentales" es una clara referencia al modernismo considerado por los ultraístas recargado de adorno y sin sustancia.

14 El traductor fue Endre Gáspár.

15 Desde el no 10 de Ultra (10 de mayo de 1921), el nombre de Peiper aparece como corresponsal polaco con su dirección de Cracovia (Jagiellońska, 5, Cracovia). Llaman nuestra atención los artículos de Emilio Quintana y Jorge Mojarro Romero y de Emilio Quintana y Ewa Palka; sin embargo, nosotros no encontramos tal información en el pie de imprenta del mencionado número de la revista.

16 Por ejemplo, las portadas de $\operatorname{los} \mathrm{n}^{\circ} 10,11,12,13,14,15,16,18,20,22,24$. Otras ilustraciones de las portadas y del interior de la revista son obras de Rafael Barradas y Norah Borges.

17 La dedicatoria de Rivas: “A Jorge Luis Borges / que ha surcado / la ruta de los conquistadores” ("Ultraísmo” 3). 
FIGURA 1

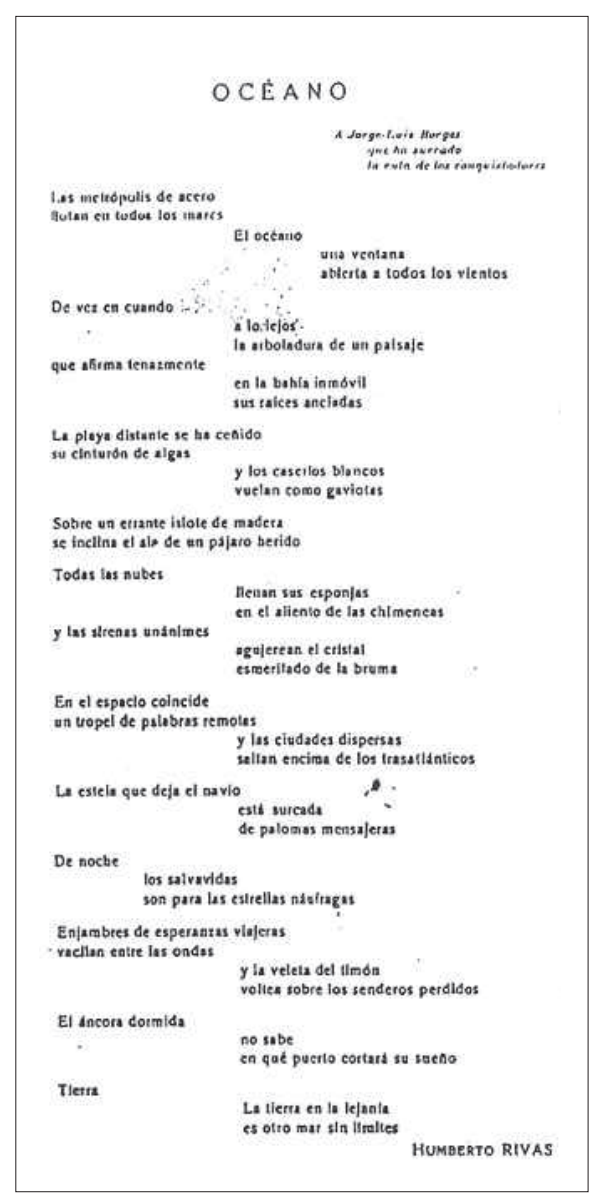

FIGURA 2

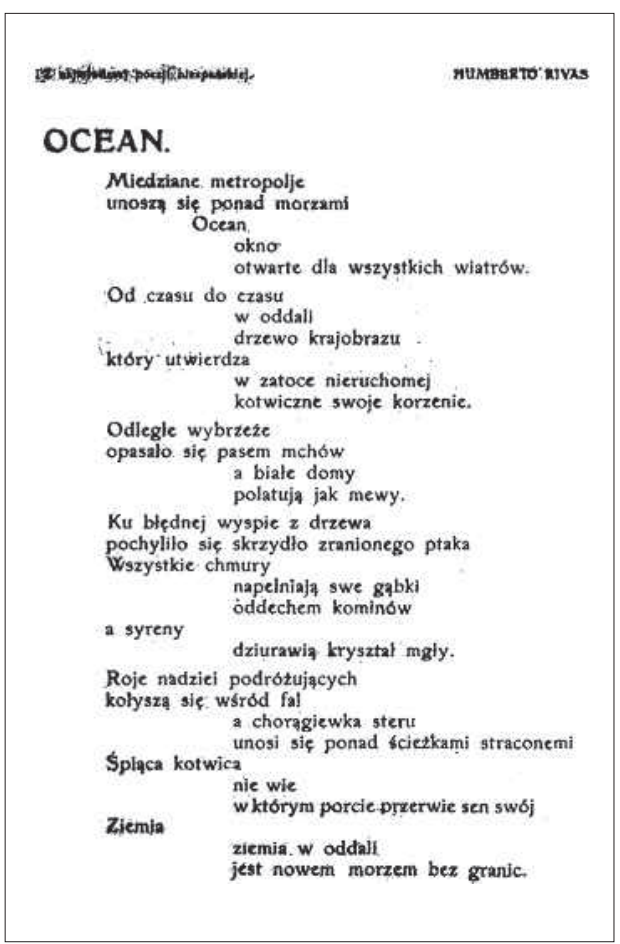

^ Rivas Panedas, Humberto. “Océano”. Formiści [Cracovia], Mayo, 1921.

\ Rivas Panedas, Humberto. "Océano". Ultra, n 12, 1921, p. 3.

Rivas Panedas, uno de los fundadores de $U l t r a,{ }^{18}$ como a su compatriota, Wladyslaw Jahl. ${ }^{19}$ El otro motivo de la elección de Peiper fue, suponemos, que el poema fuera un ejemplo perfecto de la estética ultraísta. Aquí reproducimos, después del original (fig. 1), no solo el texto de la traducción polaca (fig. 2) sino también el de la húngara (fig. 3), para ver las semejanzas entre las dos versiones y las diferencias entre estas y el poema en español.

18 En el primer número, los fundadores de la revista declararon que Ultra no tenía director, sino que la dirigía una junta con colaboradores permanentes, entre ellos los hermanos Rivas Panedas (José y Humberto), Lasso de la Vega, Guillermo de Torre, Jorge Luis Borges y Wladyslaw Jahl. En la práctica, sin embargo, Humberto Rivas y Jahl hicieron la mayor parte del trabajo.

19 Rivas y Jahl eran buenos amigos. Lo atestigua también la dedicatoria al pintor polaco que Rivas Panedas hizo de su poema "Amanecer" (1921c), publicado en el no 10 de Ultra. 
FIGURA 3

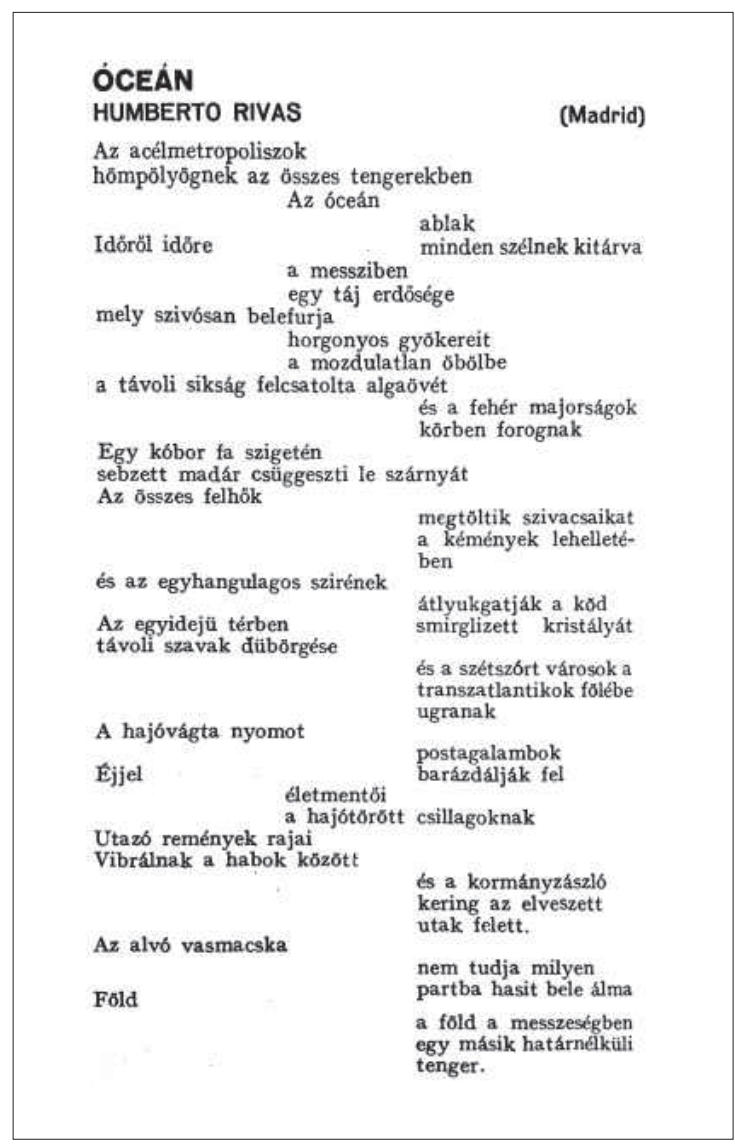

Rivas Panedas, Humberto. $M a, \mathrm{n}^{\circ}$ 8, 1921, p. 102.

Volviendo a la problemática de la traducción, a primera vista es perceptible que la versión polaca se distingue bastante del poema en español. Aunque en la tipografía la traducción de Peiper sigue más o menos fielmente la forma del poema original, cuyos versos constituyen casi dos columnas paralelas -con algunos versos más largos que así se extienden y rompen la línea tipográfica de la segunda columna-, si contamos los versos ya podemos constatar una gran diferencia entre el texto de Rivas y el de Peiper: el poema español consta de cuarenta y tres versos, mientras que el polaco solo de treinta y dos. La versión húngara, con sus cuarenta y dos versos, es más fiel a la forma del poema español, aunque esta versión tampoco es exacta, porque en la traducción de Endre Gáspár los versos de las dos columnas a veces se lindan, y este fenómeno no aparece en el poema de Rivas Panedas.

Sin conocer el idioma polaco, tenemos que basarnos en un estudio que analiza la traducción de Peiper. Según los autores de este ensayo, el traductor no solo abrevió 
la obra con once versos, sino que con esta eliminación transformó también el contenido del poema. La versión abreviada es más bien un poema autónomo en polaco, creación propia de Tadeusz Peiper que se basa en el poema ultraísta de Humberto Rivas (Quintana y Mojarro Romero). Tenemos la impresión, si seguimos la lectura de los investigadores, de que el traductor quiso escribir un buen poema polaco sobre la base de otro poema.

La traducción húngara es fiel al poema español no solo en su forma sino también en su contenido. En la distribución de los versos encontramos diferencias entre el texto húngaro y el español solo en un punto, que el poema en húngaro cuenta de un verso menos que la poesía original: los versos doce y trece de Rivas (La playa distante se ha ceñido / su cinturón de algas) se fusionan en uno en la traducción de Gáspár (a távoli síkság felcsatolta algaövét), pero sin cambio de significado. En cuanto a las imágenes, la traducción húngara pierde fuerza solamente en una comparación, en los versos catorce y quince: "los caseríos blancos / vuelan como gaviotas", leemos en Rivas, que en húngaro será: "a fehér majorságok / körben forognak” (que significa: los caseríos blancos dan vueltas), es decir, falta la segunda parte de la comparación (como gaviotas = mint sirályok), y por eso desparece del poema la gaviota, pájaro infaltable del cielo sobre el océano.

En el siguiente número de $M a-n^{\circ} 9$ (5 de septiembre de 1921)- encontramos otro poema traducido del español, esta vez de un autor hispanoamericano: "Rusia" de Jorge Luis Borges. La obra del poeta argentino se publicó por primera vez en la revista Grecia, en 1920, con la xilografía de Norah Borges, hermana menor del poeta (Borges, "Rusia” 7). Este poema temprano de Borges lleva aún las huellas del expresionismo, y nació en el mismo periodo que las poesías "Trinchera", "Hermanos", "Gesta maximalista” y "Guardia roja”. ${ }^{20}$ Aunque la obra está versificada (fig. 4), el poema de Borges se publicó en la revista Grecia como si estuviera escrito en prosa, sin división (fig. 5). La traducción húngara -semejantemente a la del poema de Rivas Panedases trabajo de Endre Gáspár y fue una de las primeras traducciones, seguida por la versión francesa, ${ }^{21}$ ocho meses más tarde (Quintana). Esta vez tampoco tenemos información sobre cómo recibió el poema Kassák; sin embargo, hay que suponer que fue Tadeusz Peiper -que llegó desde Madrid a Viena- quien dio al escritor húngaro el no 23 (noviembre de 1920) de Cosmópolis, editada en la capital española, y en la que se publicó por segunda vez - después de Grecia- la obra de Borges, entonces ya en forma de poema (fig. 6).

También apoya nuestra sospecha la documentación del archivo del Museo Kassák de Budapest, que guarda carpetas con el título Idegen fordítások - antológia anyag

\footnotetext{
20 Sobre la génesis, el manuscrito y la publicación de "Rusia", hay más detalles en el artículo de Carlos García (ver bibliografía).

21 Traducido por Jacques Lothaire y publicado en mayo de 1922.
} 
FIGURA 4

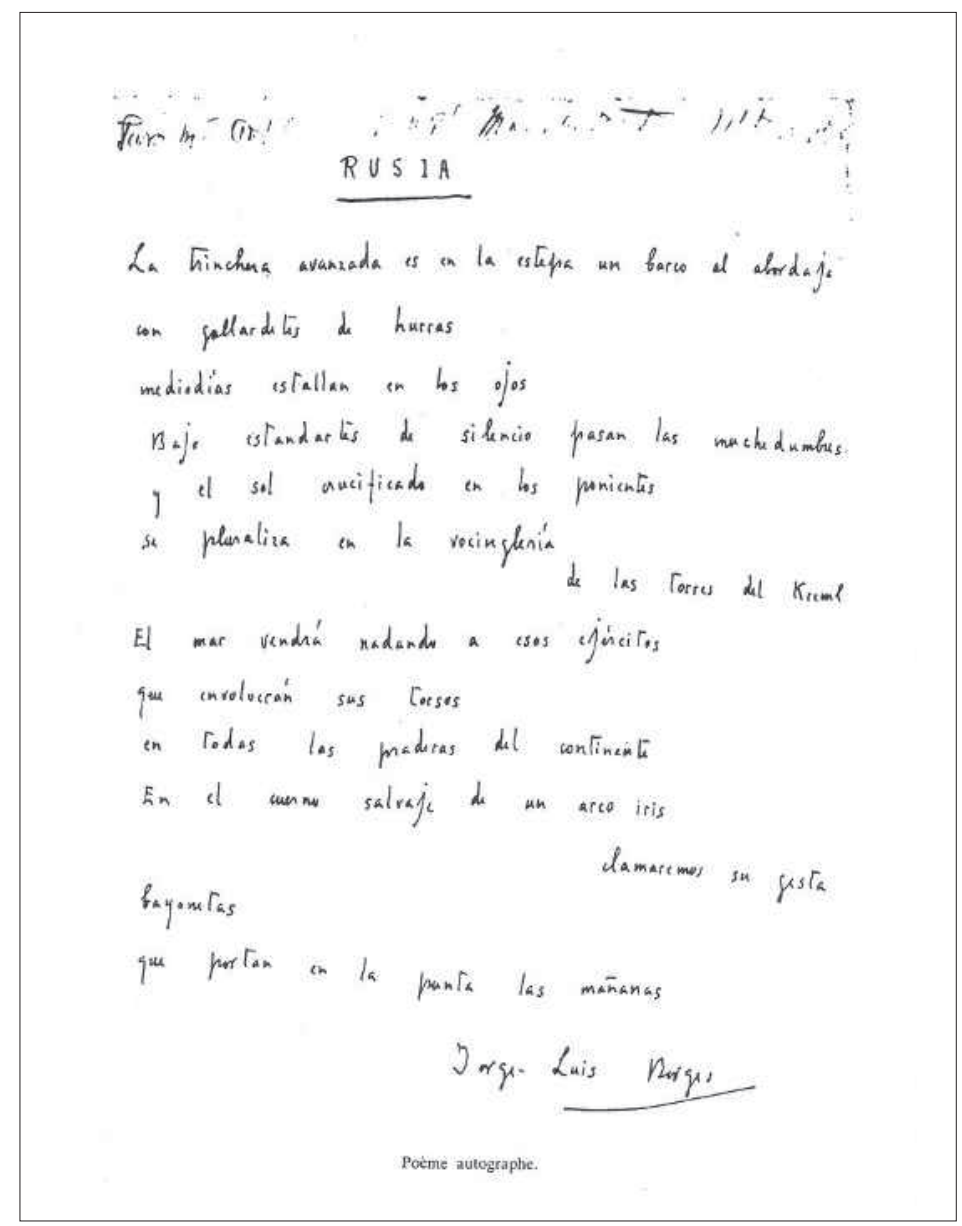

Borges, Jorge Luis. "Rusia”. Foto del manuscrito.

FIGURA 5

\section{R U S I A}

La trinchera avanzada es en la estepa un barco al abordaje con gallaz detes de hurras: mediodias estallan en los ojos, Bajo estandartes de silencio pasan las rauchedumbres y el sol cruciflcado en jos ponientes se pliraliza en la vocingleria de las torres del Kreml. El max vendrá nadando a esos ejércitos qué envolverán sus torsos en todas las praderas del continente. bìn el cuerno sal. vaje de un arco iris clamaremos su gesta bayonetas que portan en la punta las maflabas.-JORGg-Lurs BORGBis

Borges, Jorge Luis. "Rusia”. Grecia, n 48, 1920, p. 7. 


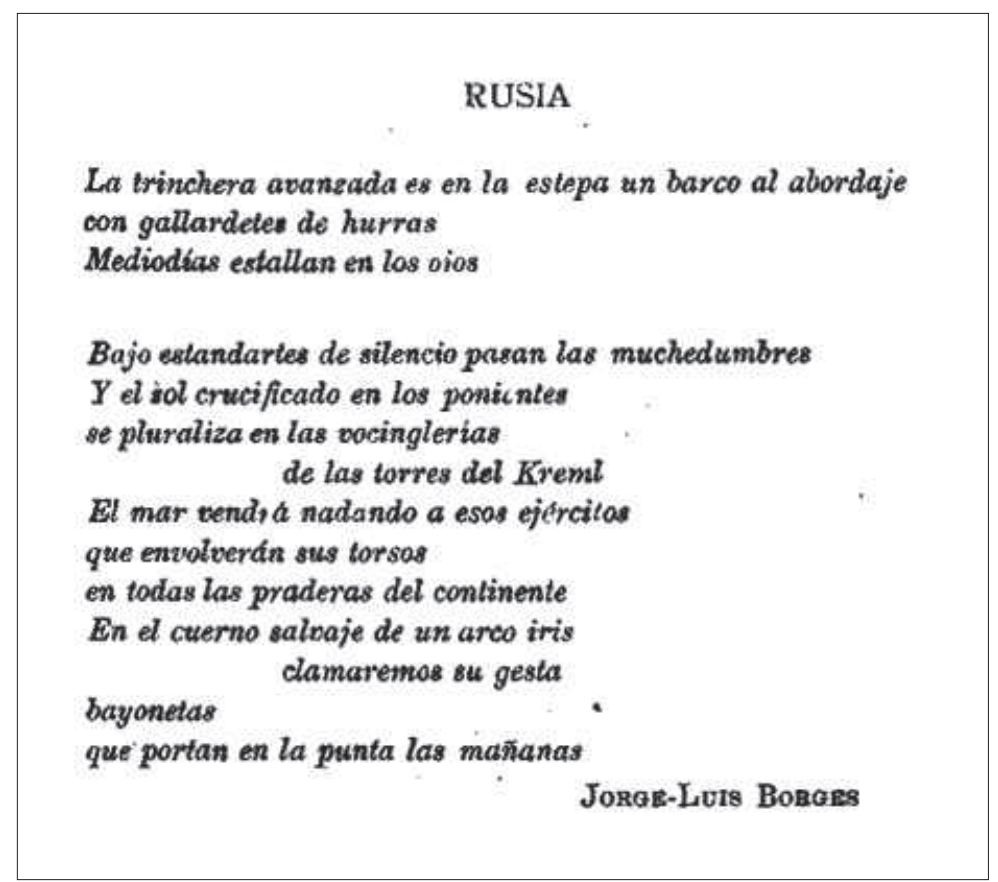

Borges, Jorge Luis. “Rusia”. Cosmópolis, n² 23, 1920b, pp. 485-6.

[Traducciones extranjeras - material para una antología].${ }^{22}$ En estas carpetas encontramos las traducciones de poemas de Eugenio Montes, Pedro Garfias, Gerardo Diego, Luciano de San-Saor, ${ }^{23}$ Humberto Rivas Panedas, Ernesto López-Parra, Juan Larrea, Joaquín de la Escosura y Guillermo de Torre, cuyas obras originales aparecieron también en el número citado de Cosmópolis. Los poemas siguen casi el mismo orden en la documentación del Museo Kassák que en las páginas de la revista española. Cabe destacar que la traducción de "Rusia" de Borges ("Oroszország" 122) mantiene la forma en verso de la versión publicada en Cosmópolis y no la forma en prosa editada por Grecia. La traducción húngara (fig. 7), fiel al poema español, no puntuación, pero con las mayúsculas distribuye el texto en seis unidades. Según nuestra opinión, el traductor logró guardar también las asociaciones visuales bastante complejas, y solo la palabra pradera (en el verso diez: "en todas las praderas del continente") se redujo algo en la palabra terei [plazas] usada por Gáspár ("a kontinens összes tereibe").

22 Las traducciones húngaras de los poemas españoles se encuentran en las carpetas KM-an., 240 y 241. Según el proyecto original de Kassák, estas poesías habrían aparecido también en Buch Neuer Künstler [Libro de Nuevos Artistas] de Lajos Kassák y László Moholy-Nagy, publicado en Viena en 1922 (Csaplár 7-13). Al final, por motivos desconocidos, los autores no seleccionaron los poemas traducidos para el libro (Csaplár 11).

23 Lucía Sánchez Saornil, poeta que publicó sus obras bajo seudónimo masculino. 
FIGURA 7

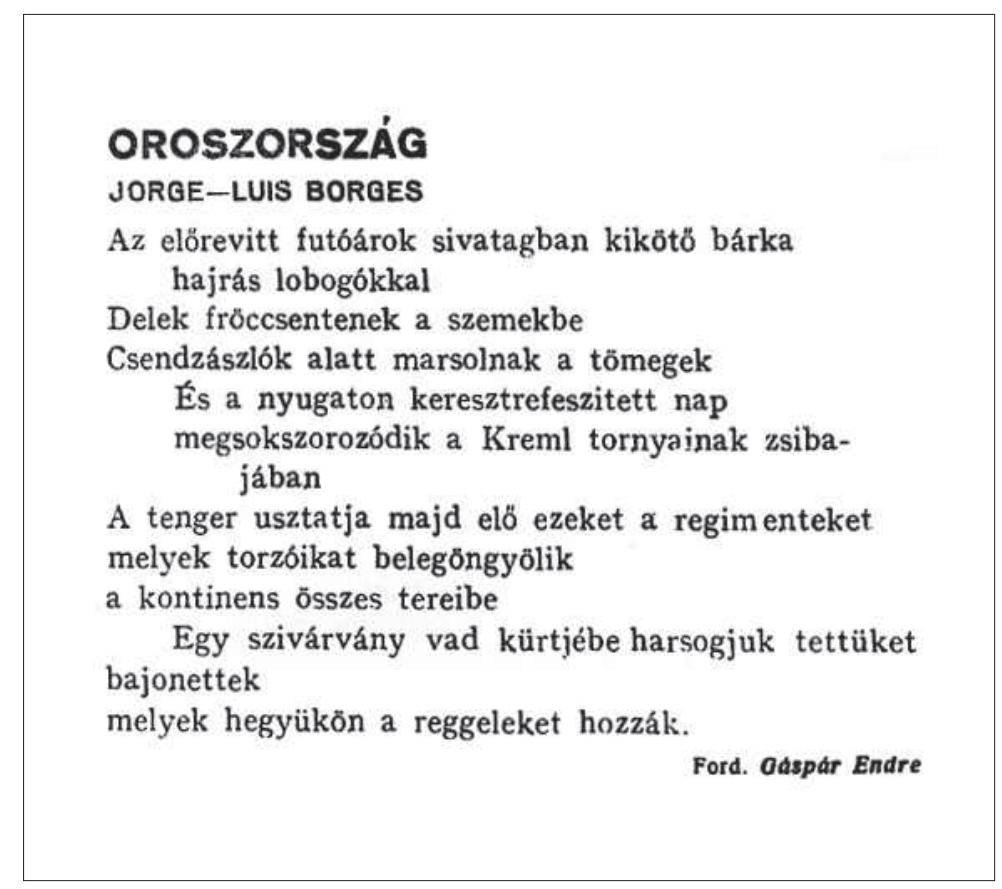

Borges, Jorge Luis. “Oroszország”. Ma, n 9, 1921b, p. 122.

En la revista $M a$ encontramos además dos poemas de un autor de habla hispana: el poeta chileno Vicente Huidobro, fundador del movimiento del creacionismo. Huidobro pronunció su famoso discurso programático Non serviam en el Ateneo de Santiago de Chile en 1914. El poeta que se identifica con Dios y con la fuerza creadora de la madre-naturaleza se rebela, alza su voz y declara que después de la esclavitud de la imitación llegó, finalmente, el momento de la libertad de la creación:

Non serviam. No he de ser tu esclavo, madre Natura; seré tu amo. Te servirás de mí; está bien. No quiero y no puedo evitarlo; pero yo también me serviré de ti. Yo tendré mis árboles que no serán como los tuyos, tendré mis montañas, tendré mis ríos y mis mares, tendré mi cielo y mis estrellas.

Y ya no podrás decirme: "Ese árbol está mal, no me gusta ese cielo.... los míos son mejores".

Yo te responderé que mis cielos y mis árboles son los míos y no los tuyos y que no tienen por qué parecerse. Ya no podrás aplastar a nadie con tus pretensiones exageradas de vieja chocha y regalona. Ya nos escapamos de tu trampa. (Huidobro s/p.) 
Las ideas de Huidobro llegaron a Europa junto con su visita al viejo continente, y tuvieron influencia sobre los artistas vanguardistas españoles y franceses. En Madrid, el poeta chileno entró en contacto con Rafael Cansinos Asséns, Ramón Gómez de la Serna y muchos otros ultraístas españoles. Entre los que asimilaron su estética se encuentran, sobre todo, Juan Larrea y Gerardo Diego. ${ }^{24}$ Con el triunfo del surrealismo, sin embargo, el creacionismo fue relegado muy pronto a un segundo plano en la poesía de la generación del 27.

En el número doble de $M a$ (n 5-6, 1 de mayo de 1922) se publicó un poema de Huidobro ("Vers" 14) -traducido por Sándor Barta- con el simple título "Vers" ["Poema”] (fig. 8). Aunque la edición húngara no da ninguna pista sobre la fuente del poema original, con una breve búsqueda logramos identificar el texto, que se titula “1914", publicado en 1918. El título del otro poema -publicado el 15 de septiembre de 1923 - es "Torony" (96), que es la traducción de la poesía "Campanario" de Huidobro, en la versión de Gyula Illyés (fig. 9).

Como curiosidad, mencionamos que Lajos Tihanyi, pintor húngaro perteneciente al círculo de Kassák, dibujó un retrato de Vicente Huidobro (fig. 10) que actualmente está en la colección de la Galería Húngara Nacional. El cuadro llegó también a España, en 1999, gracias a la exposición Lajos Kassák y la vanguardia húngara, organizada en el IVAM. ${ }^{25}$

En la segunda mitad de la década de los diez y en los primeros de la década de los veinte aparecieron tanto en España como en Hispanoamérica nuevas tendencias literarias, unos ismos cuyo objetivo fue romper con la herencia rubendariana y con la estética modernista. Las premisas pronunciadas en los diferentes manifiestos -como por ejemplo, la renovación del lenguaje poético tradicional, la disolución de la sintaxis, la eliminación de la métrica y las rimas, el uso de imágenes poéticas desconcertantes, las soluciones tipográficas novedosas, la importancia de los elementos visuales, la fragmentación, la discontinuidad y la composición simultánea- se realizan en los poemas.

Con las cuatro poesías publicadas en las páginas de $M a$, la revista húngara representó solo algunos colores de los ismos de habla hispana; sin embargo, su empresa fue única y excepcional, visto que las traducciones húngaras fueron publicadas casi paralelamente a la aparición de los poemas originales en revistas españolas. Así, los lectores húngaros pudieron leer estos poemas casi al mismo momento que los lectores de habla hispana.

24 Los poemarios de Diego que mejor muestran la influencia del creacionismo huidobriano son Imagen (1922) y Manual de espumas (1924).

25 El dibujo se encuentra también en el álbum de la exposición (VV.AA., Lajos Kassák y la vanguardia húngara 196). 
FIGURA 8

\section{VERS}

VINCENTE HUIDOBRO

(SPANYOL)

Nyármeleg szökökutak fölött felhök Éjszaka

Európa valamenyi tornya beszédbe kezd

Egy szem hirtelen látásba tágul egymással

A holdtülök kiált

Hallali

Valamennyi tornyok felaggatott tülkök

\section{Hallali}

1914 Augusztus

A határok szürete ez

Valami felágál a horizont mögött

A városok mind ott himbálnak a hajnal keresztjén

Mint pipák füstölögnek metropoli-

Hallali szok

És ez nem ének

Hallali

Emberek menetelnek

F.rd: Barta Sándor

Huidobro, Vicente. “Vers". Traducción de Sándor Barta. Ma, n 5-6, 1922, p. 14.

FIGURA 9

\section{Torony}

Harangok minden hangjára

Érc madarak

kiröppen egy madár

Hálnak a palatetőn

HOVA HULLOTT A LEGELSÓ DAL

Minden este

Ez az örömtüz

Minden levélben sziv repes

És minden lépésnél csillag gyullad

A szemek valamit örzenek

Mi hangodban remeg

Fönt a Zenitnek hegytetején

Egy óra

folyton ürül

Ford.: IIIes Gyula

Huidobro, Vicente. “Torony”. Traducción de Gyula Illyés. Ma, nº 1, 1923, p. 98. 


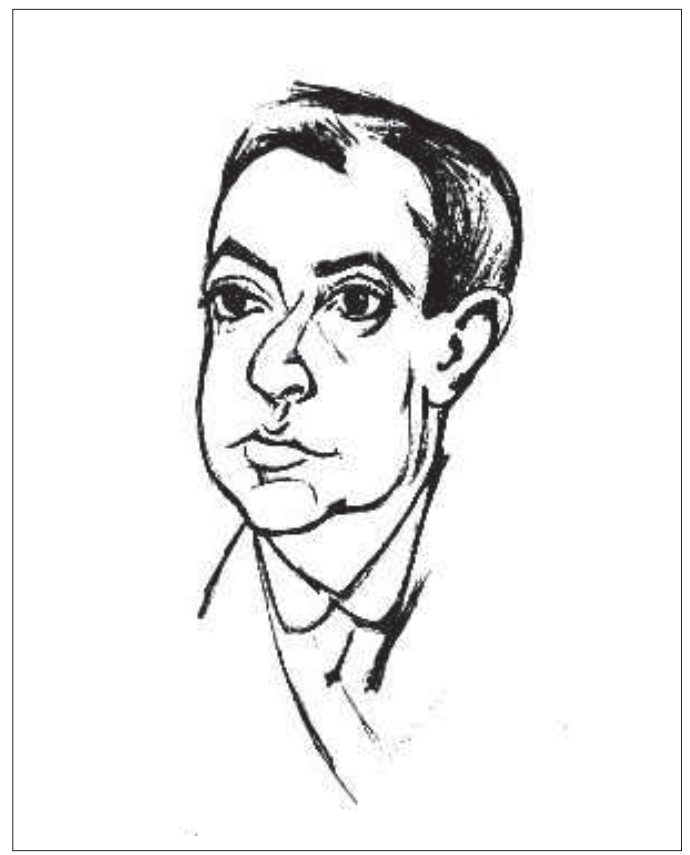

Tihanyi, Lajos. "Vicente Huidobro" [dibujo]. VV. AA. Lajos Kassák y la vanguardia húngara. Valencia, IVAM Centre Julio González, 1999, p. 196.

\section{La revista Munka [Trabajo]}

La revista Munka [Trabajo] fue la publicación más duradera de Kassák, publicada desde 1928 hasta 1939. La revista se definió como "informe artístico y social” y puso en primer plano, a diferencia de las revistas anteriores, temas concernientes a la política, la sociología y la economía. El cambio de perfil se observa también en la mayor cantidad de artículos que informan sobre la situación de la política española de la década de los treinta: algunos resúmenes sobre la agitación del comienzo de la década (1930-1931) y el cambio de forma de Estado, la proclamación de la Segunda República española, mientras que otros artículos se concentran en las elecciones de 1936, el triunfo del Frente Popular y, en 1937, ya se incluyen noticias sobre los acontecimientos de la Guerra Civil. Dos de los artículos -firmados por Dauphin-Meunier y Gorkin-son traducciones, pero los otros son escritos por autores húngaros: Imre Vajda, Ervin Falus, Endre Havas y Lajos Kassák.

La revista tenía una sección dedicada a la política extranjera. El autor de estos artículos fue Imre Vajda, y en más escritos suyos encontramos alusiones a la política de España. En el no 12 (1930) de Munka encontramos un informe exhaustivo sobre la política mundial del momento. El último párrafo del artículo menciona la abdicación de Primo de Rivera como un "acontecimiento de envergadura aún imprevisible" (Vajda, 
"Világpolitika" 360), y el periodista escribe que no se sabe aún las consecuencias políticas de este hecho: “¿Con la desaparición del General termina también la dictadura?” (360) -pregunta Vajda-. Al terminar el artículo, el autor húngaro expresa también su confianza en la fuerza del proletariado español.

En el siguiente número de la revista (n 13 de 1930), Imre Vajda, en su reseña sobre la situación de la política mundial, vuelve al caso de España después de la caída de la dictadura de Primo de Rivera. Constata que la salida del dictador en vano, porque el gobierno de Dámaso Berenguer sigue con los mismos métodos autoritarios. Gran diferencia, no obstante, habría entre los dos sistemas -según Vajda-, pues mientras Primo de Rivera tenía confianza en su sistema, el General nombrado por Alfonso XIII siempre vacila y es incierto: a veces prohíbe las duras órdenes de su predecesor y otras veces él mismo hace entrar en vigor otras leyes aún más severas. Sigue la prohibición de la libertad de prensa y tampoco hay libertad de reunión, y la policía disuelve con violencia a la multitud descontenta. Vajda ve claramente que se trata de la cuestión de la persistencia o de la caída de la monarquía, por lo que escribe que es un "problema urgente de carácter revolucionario" ("Világpolitika” 396). El simple relevo personal -es decir, Berenguer en el lugar de Primo- no satisface a la multitud antes silenciada, pero hoy pensativa y con sentido crítico. "La idea de la revolución sigue expandiéndose y arrastra a capas sociales cada vez más amplias" (396) -sigue el periodista-. Vajda termina su artículo con una pregunta: ¿qué carácter tendrá la revolución española si logra triunfar, y cómo será la nueva España? El planteamiento de la pregunta es aún -admite Vajda- adelantado; sin embargo, expresa su confianza, esperando que el ejemplo español -si resulta exitoso- sea "un rayo de luz en las tinieblas y un ejemplo de seguir" para los obreros socialistas de Europa (396).

En el no 17 (1931) de Munka podemos leer el artículo de Achille DauphinMeunier sobre "Los estudiantes y la revolución española", en traducción húngara. El periodista, economista y jurídico francés nos ofrece un diagnóstico sobre los disturbios de España de los años treinta: resume las últimas horas de la dictadura, los problemas políticos, sociales y económicos de la crisis actual y plantea el dilema de cómo seguir adelante. Entre los problemas, menciona la fuerte fluctuación del valor de la peseta, el desorden de la infraestructura, la inflexibilidad del mercado interior, los enormes gastos de la Guerra del $\operatorname{Rif}^{26}$ y, como consecuencia de todo eso, que el país sufre aún más las consecuencias de la crisis económica mundial. Junto con los obreros socialistas, republicanos y anarcosindicalistas, los estudiantes son cada vez más decididos y forman "el grupo más fuerte de la burguesía liberal y revolucionaria" (Dauphin-Meunier 471); su fuerza ya pone en peligro a la dictadura clérigo-militar, los círculos de la oligarquía y también la monarquía. La privación de los derechos

26 En el protectorado español y francés de Marruecos se desarrolló una sublevación tribal contra la administración colonial. Las luchas empezaron en 1911 y se prolongaron hasta 1927. En 1927, Primo de Rivera - con el apoyo de los franceses- logró terminar la guerra, que duraba ya dieciséis años. 
de la burguesía y su exclusión del poder es otro foco de conflictos, visto que "la burguesía quiere llegar al poder de donde Primo de Rivera y Berenguer la excluyeron" (471) -escribe el periodista francés-. El mayor dilema es cuál será la adecuada forma del poder que podrá construirse en las ruinas de la monarquía, después del derribamiento de la dictadura. Según Dauphin-Meunier, la burguesía no tiene respuesta a esta pregunta. Y, aunque los grupos de los estudiantes, en su mayoría de familias burguesas, organizan bien sus fuerzas contra el poder, en cuanto al futuro, no tienen una voz unánime: "Organizaron perfectamente la huelga universitaria [...] y pudieron luchar y morir en las barricadas. Se sacrificaron con coraje y heroicidad. Ayer [...] solo murmuraron, hoy ya luchan hombro a hombro. Actúan unidamente, sin embargo, a pesar de unir sus fuerzas contra la dictadura, no pueden ponerse de acuerdo en cuanto al sistema del futuro" (471). La falta de acuerdo entre los estudiantes es el fiel reflejo de toda la sociedad española: algunos - "como revolucionarios conscientes" (471) - están bajo la influencia de los anarcosindicalistas y, en cuanto a sus intereses, se identifican con el proletariado. Mientras que los otros - sobre todo en las grandes ciudades y en Madrid- se declaran republicanos y reformistas y aspiran al poder político. Dauphin ve claramente que esta imposibilidad de llegar a un acuerdo en el bando de la oposición obstaculiza que España pueda volver al sistema democrático. Esta divergencia en la izquierda, como es bien sabido, no cambiará ni en los años de la Segunda República, determinando así el fracaso de las fuerzas democráticas desde 1934. Merece la pena citar las ideas finales del artículo del economista francés, ya que estas palabras se dirigen no solo a los estudiantes sino a toda la oposición española:

Los estudiantes españoles tendrán que elegir en breve entre el régimen republicano- parlamentario de la burguesía y el régimen proletario organizado por los comunistas o los sindicalistas. La abdicación del rey y la caída de la dictadura no tardaron mucho. Entonces ¿qué hay que construir en las ruinas de la monarquía? Los anarcosindicalistas cederán la organización del sistema político, sin duda, a los republicanos porque ellos tienen que concentrar toda su fuerza en la organización de la economía. Un día, pero, uno de los dos poderes tiene que doblegarse ante el otro. ¿Cómo reaccionarán entonces los estudiantes? ¿Acaso será total la ruptura ideológica cuyas huellas ya se ven hoy día, o el miedo conduce a los estudiantes universitarios -que coquetean ahora con el proletariado- al bando de los republicanos? (471).

El escrito de Dauphin-Meunier termina sin conclusión y plantea la pregunta: ¿qué viene ahora, 1905 o 1917? ¿Recibirá España la ilusión del régimen democrático, como sucedió con los rusos que recibieron la Duma, o pisará el camino de la revolución social? Si elige este último, los campesinos recibirán las tierras, los obreros de las fábricas controlarán la producción y las juntas provinciales y municipales tomarán el poder político (471). La proclamación de la Segunda República Española y la Guerra Civil de tres años darán la respuesta a esta pegunta. 
En el n¹8 (1931) de Munka podemos leer una "Carta desde Madrid” de I. G. Gorkin, en la que el autor comunista - con su nombre de nacimiento Julián Gómez García- nos resume sus experiencias al volver a la capital española. Gorkin emigró a Francia en 1922 para escaparse del reclutamiento para la guerra de Marruecos. En París, como "revolucionario profesional", adhirió a la Internacional Comunista y editó revistas revolucionarias en español (El Proletario, La Luz, La Verdad, Adelante). En 1929 lo alejaron de la organización comunista por desviación ideológica. Después empezó a trabajar como periodista y traductor, y publicó también obras literarias. Volvió a su patria tras la caída del régimen de Primo de Rivera, durante la "dictablanda" de Berenguer. La carta publicada en la traducción húngara describe justamente este momento. La carta se escribió, pues, en mayo de 1931, poco después de la proclamación de la Segunda República Española.

La descripción en estilo documentalista -aunque no le falta tampoco el registro literario- eterniza el día cuando Gorkin, después de pasar casi diez años lejos de su patria, vuelve a su tierra natal. Ya en el tren se sumerge en sus propias reflexiones al ver los muchos cambios que sucedieron en España durante su ausencia: entonces tuvo que huir para que no le alistaran al ejército y ahora la gente habla sobre la República y la revolución. Sin embargo, la impresión de Madrid destruye toda la ilusión de la espera: iglesias en llamas, persecución de los eclesiásticos, linchamiento de los miembros del gobierno, los coches encendidos de los sujetos relacionados con la monarquía y los quioscos en ruinas de la prensa católica. La República y la nueva política no realizaron las esperanzas de la gente. “¿Por eso echamos a la calle a Alfonso? Si el gobierno no se siente suficientemente revolucionario, entonces ¡abajo con él!” (491) -resume Gorkin señalando la indignación de la multitud-. Pero el pueblo no se deja engañar: "la revolución empieza ahora" (491) -escribe-. Maura, el ministro de Gobernación, fue acogido por la gente de la calle con gran ovación solo hace un mes, pero ahora no le dejan hablar. La revolución -sigue el autor- necesita revolucionarios verdaderos y no hombres oportunistas que aparecen y desaparecen a cada momento. La ruptura, apenas un mes después del nacimiento de la República, se sentía no solo entre la voluntad del pueblo y el gobierno sino también entre los partidos políticos. La extrema izquierda ya entonces criticó severamente al gobierno y atacó, en primer lugar, al primer ministro y al ministro de Gobernación.

El escrito de Gorkin expresa, pues, la desilusión que la gente sintió apenas después de la euforia pasajera de la República. La carta refleja bien la posición de la extrema izquierda de Gorkin y no calla tampoco su esperanza: "El pueblo no dejará defraudar la revolución [...]. El pueblo español no dejará silenciar su revolución" (491).

El artículo de Ervin Falus es algo más tardío que la carta de tono personal de Gorkin, pero aún es del mismo año, 1931, y su título es "Las preguntas de la revolución española”. Se trata de un profundo análisis sociopolítico sobre el caso español, pero el autor coloca la situación política del país en un contexto mucho más amplio, y la analiza entre los marcos del movimiento obrero internacional. Hace una comparación entre 
la revolución española y la rusa, y constata que hay tanto semejanzas como diferencias entre ambas. Semejanzas en cuanto a "sus posibilidades y condiciones materiales" y diferencias en cuanto a "la preparación revolucionaria de las masas" (538).

El periodista enumera los puntos en común entre las dos revoluciones: 1. la importancia de la cuestión agraria y el feudalismo agrario que defiende obstinadamente sus tierras, su poder económico y sus fueros; 2 . la capitalización muy tardía y sin fundamentos que agrava la cuestión de las nacionalidades (catalana y vasca), ${ }^{27} 3$. la burguesía inexistente; 4 . el carácter especial del poder y la peculiar situación del ejército; ${ }^{28} 5$. el enorme poder de la iglesia. Otro motivo común entre la revolución española y la rusa es la división del proletariado: los obreros industriales, en mejor situación económica, están en una minoría bien organizada frente a las masas campesinas más atrasadas (538). Justamente en este punto ve Falus la mayor diferencia entre el caso español y el ruso, porque en Rusia los obreros industriales reconocieron el principio de la vanguardia y asumieron este papel. La revolución rusa fue el resultado de una preparación y organización conscientes: "El proletariado ruso se prepara para la revolución, elabora y organiza todos los puntos del plan" (538). La revolución española, al contrario, elige otro camino cuando destaca la importancia de la lucha económica y rechaza la idea de la unidad política: "En la cuestión de la revolución profesan la espontaneidad y la intuición, porque su principio no es la revolución organizada sino la huelga de masas que brotaría espontáneamente de la lucha económica" (539). Falus no duda en la fuerza revolucionaria de esta última, pero subraya la falta de la consciencia. El sindicalismo español -sigue el periodista- rechaza el poder actual y considera al gobierno como una fuerza opresora. Sus demandas -eliminación del analfabetismo, disminución del paro, libertad de prensa, derecho a la huelga y a la reunión - fundamentalmente son exigencias del programa de una revolución burguesa radical; sin embargo, el gobierno republicano, por un lado, no puede, y por otro lado, no quiere cumplirlas.

Las huelgas de masas tuvieron sus consecuencias negativas: el sindicalismo fue declarado ilegal y los obreros que pertenecían al movimiento sindicalista tuvieron que sufrir una persecución similar a la que habían experimentado ya durante la dictadura de Primo de Rivera. Está probado -escribe Falus- que el sindicalismo va por un camino equivocado. El proletariado español tiene que encargarse de la liquidación del sindicalismo y, en este trabajo, la revolución española cumple una gran tarea histórica -concluye el periodista húngaro-.

Falus critica también la coalición del partido socialdemócrata -que está en el poder- con la burguesía republicana y hace un elenco de los partidos de los obreros: 1 . el partido comunista; 2 . la federación catalana; 3 . la alianza de los obreros y los campe- 
sinos; 4. el grupo trotskista (540). Aunque la representación numérica del proletariado no es muy elevada, Falus piensa que no es ese el problema fundamental, sino que su falta de organización y la lucha entre sus grupos. Estos son los mayores defectos que imposibilitan su acción en conjunto. "El proletariado español no tiene partido líder" (541); así, el objetivo primordial es la realización de la unidad del partido -escribe-.

Resumidos los resultados de la revolución española, Falus reconoce que esta abolió a la monarquía, reveló los problemas sociales y, además, indicó la importancia de la liquidación del sindicalismo y la creación de un partido dirigente. En este punto, la primera parte de la revolución termina, y la lucha por las masas y la liquidación histórica del sindicalismo designan el camino para seguir en el futuro. Desde el punto de vista del movimiento obrero internacional, Ervin Falus señala la importancia de la revolución española justamente en este aspecto.

Otros dos escritos de contenido político aparecieron en las páginas de Munka aun antes del estallido de la Guerra Civil, en 1936. El autor del primero es Endre Havas, y su artículo apareció bajo el título "Dokumentumok" ["Documentos"], texto en el que da un panorama completo sobre la política mundial. Allí, dirige su atención hacia los Estados Unidos, Alemania, Inglaterra e Italia y, detallando los focos de conflictos, menciona a España como un ejemplo positivo: "En este momento de crisis, el triunfo del Frente Popular español puede tranquilizarnos porque tiene fuerzas junto a las ideas de la izquierda" (1448) -escribe-. Este éxito de la izquierda tendrá influencia probablemente sobre las elecciones francesas -opina Havas-. Los socialistas -con su líder, Largo Caballero- prometen trabajo verdadero y la corrección de los errores del pasado. El artículo cita un fragmento del discurso de Largo Caballero publicado originalmente en el periódico madrileño El socialista: "La España trabajadora y pensadora cosechó su verdadero triunfo el 16 de febrero de 1936 -que bien sobrepasa la importancia del 14 de abril de 1931 - porque solo ahora, después de la ofensiva del bienio negro podemos ver claramente lo que queremos, y solo ahora estamos preparados para realizar nuestra voluntad" (1453). Este discurso optimista, sin embargo, no se hizo realidad, ya que apenas cinco meses después empezaría la Guerra Civil española.

El artículo de Lajos Kassák, con el título "Reflexiones”, apareció cuatro meses después del estallido de la guerra española. Aunque Kassák no se considera experto ni en temas militares ni en asuntos políticos, opina que hacer reflexiones sobre los acontecimientos que suceden en la península ibérica es obligación de un intelectual ("Reflexiók" 1611). No silencia su objetivo: incitar a los lectores a la reflexión.

Kassák considera la Guerra Civil de mayor trascendencia que la Revolución francesa en cuanto a su ardor y a sus sacrificios. Desde el punto de vista psicológico -opina-, el conflicto español es aún más fuerte y cruel que le Revolución rusa que sacudió todo el mundo en 1917. El pronóstico de Kassák podría parecer al lector de entonces -en 1936- algo exagerado pero, conociendo el resultado de la guerra que se prolongó por tres años, podemos decir que no lo era. El escritor constata que los rebeldes se equivocaron en sus cálculos cuando querían terminar la lucha en un mes. 
Madrid -escribe en diciembre de 1936- estaba aún en las manos de las tropas del gobierno republicano. La guerra puede prolongarse mucho "ya que uno de los bandos tiene la superioridad militar, mientras que las masas dispuestas al sacrificio apoyan al otro lado" (1611). Sin embargo, en realidad, ninguno de los dos bandos tiene fuerzas unidas. La única excepción es el ejército colonial que durante la historia siempre servía con ciega obediencia a la voluntad de un poder superior. La crítica de Kassák es fuerte pero realista: "la gran potencia de antaño que tenía posición dirigente no solo en la economía sino también en la cultura, hoy día es uno de los países más miserables. Casi no tiene peso en la política internacional" (1607) -escribe-. Llama la atención de los lectores también respecto a la fragmentación de la izquierda, mencionando seis diferentes partidos ${ }^{29}-\mathrm{y}$ sus numerosas fracciones- dentro del Frente Popular. Por eso es imposible una estrategia única y la cooperación. Si no llegan a un acuerdo, no es posible la victoria. Sin embargo, la falta de unidad se manifiesta también en el bando de los rebeldes, ya que los seguidores de Franco también pertenecen por lo menos a tres tendencias ${ }^{30}$ bien distintas en sus ideas y políticas. El objetivo de los generales es obvio: romper la fuerza de la izquierda y erradicar las raíces del movimiento socialista. Sin embargo, la pregunta - ¿qué sucederá después de obtener el poder?- está aún abierta. Las divergencias en la derecha tampoco son muy prometedoras. Sin embargo, si imaginamos la victoria de la izquierda, tampoco esperamos posibilidades más felices para el futuro. Si en una guerra de vida o muerte son incapaces de llegar a un acuerdo, es poco probable que al llegar al poder -en caso de victoria-pudieran olvidar toda rivalidad anterior y llegar a un acuerdo. El gobierno republicano es incapaz de formar un ejército disciplinado, lo que también reconoció Largo Caballero en el consejo de ministros de noviembre. Uno de los errores más graves de la izquierda, según Kassák, es que no se preparó conscientemente para la toma del poder y, luego, tampoco pudo aprovechar las posibilidades de este. El mayor error, sin duda alguna -sigue el fundador de la revista-, es que el gobierno no realizó las reformas prometidas y, entre estas, no logró solucionar la reforma agraria. El gobierno no solo no cumplió su programa social, sino que tampoco se dio cuenta de la movilización y de la organización de los conspiradores.

Kassák intenta buscar respuestas a preguntas estratégicas y militares. Si Madrid no tiene ninguna importancia desde el punto de vista estratégico, entonces qué sentido tiene tanto derramamiento de sangre - pregunta-. Y responde: "desde el punto de vista militar, el cerco de la capital es solo un despilfarro de hombres y de máquinas" (1610). Considerando el papel de las potencias extranjeras, opina que la intervención soviética muy tardía - frente a la ayuda que ofreció Alemania e Italia a

29 Anarquistas, sindicalistas, socialdemócratas, comunistas, trotskistas y los radicales burgueses.

30 Los requetés (unas ochenta mil personas), los jóvenes de la Acción Católica (aproximadamente unas veinticinco mil personas) y la Falange. En cuanto al número de los miembros de esta última, Kassák constata que es el grupo más numeroso de los tres mencionados ("Reflexiók" 1608). 
Franco en el primer momento del conflicto- es la responsable por la actual situación desesperada del Frente Popular. A pesar de las dimensiones internacionales cada vez más amplias de la guerra española, Kassák -en diciembre de 1936- no creía probable que el conflicto se convirtiera en una guerra mundial. Se equivocó, como sabemos, ya que los historiadores consideran la Guerra Civil española como el ensayo general de la Segunda Guerra Mundial. Kassák, no obstante, observaba ya aquel entonces, con clarividencia, que toda España se transformaría en escombros, aunque el escritor húngaro aún no pensaba que la guerra fratricida se prolongaría todavía dos años y medio más. Como conclusión, expresa su certeza de que "el entusiasmo de las masas frente a la fuerza militar organizada es insuficiente para la victoria" (1612). Es decir, en el invierno de 1936, Kassák juzgaba cada vez menos probable el triunfo del Frente Popular y, podemos decir, que su opinión no fue irreflexiva.

\section{La revista Kortárs [Contemporáneo]}

En orden cronológico, la siguiente revista de Kassák fue Kortárs [Contemporáneo], en la que no era tan fuerte el perfil social y, semejantemente a la revista anterior $\mathrm{Ma}$ [Hoy], otra vez la literatura recibió mayor atención. La revista se publicó cada dos semanas y se la consideraba como la publicación literaria y artística más importante en la Hungría de la posguerra. Respecto de la literatura española, en Kortárs encontramos cinco poemas y un estudio de crítica literaria.

En 1947 se publicaron tres romances del Romancero gitano de Federico García Lorca: "San Rafael", "El romance de la pena negra" y "El romance de la luna, luna". El poemario más famoso del poeta granadino vio la luz en húngaro justamente en 1947, y en seguida en dos traducciones ${ }^{31}$ y en dos ediciones diferentes. ${ }^{32}$ Sin embargo, las primeras versiones húngaras no despertaron ningún interés entre los lectores y tuvimos que esperar hasta las traducciones de László Nagy, ${ }^{33}$ elogiadas por muchos en grado superlativo. ${ }^{34}$

La introducción anterior a los poemas publicados en Kortárs menciona también los títulos de los mayores dramas ${ }^{35}$ de García Lorca y las circunstancias de su muerte. Aunque Lorca durante décadas fue considerado por los lectores húngaros como el poeta mártir y el poeta del pueblo, esta introducción subraya que el poeta granadino nunca escribió poemas políticos. A pesar de eso, "se convirtió en una figura simbólica para el pueblo español oprimido" ("Három spanyol románc" 76).

31 Los traductores fueron László András y Ervin Gyertyán.

32 Editadas por las casas editoras Lux y Cserépfalvi, en 1947.

33 Estas traducciones vieron la luz en el tomo Federico García Lorca válogatott müvei [Obras selectas de Federico García Lorca] (1963).

34 Sobre las traducciones húngaras de la obra tanto poética como dramática de García Lorca vea: Katona. 35 Sobre la recepción de la obra dramática de García Lorca en Hungría, ver Katona, Así que pasen 60 años.... 
El poema de Pablo Neruda, "El general Franco en los infiernos", tiene una estrecha relación temática con la Guerra Civil. El poeta chileno vivió en Madrid entre 1934 y1939, así fue testigo cercano del conflicto español y dedicó al tema incluso un poemario entero con el título España en el corazón (1937). El poema publicado en Kortárs (Neruda, "Franco tábornok a pokolban") apareció por primera vez en Futuro. La revista mexicana, fundada en 1933 por Vicente Lombardo Toledano, se ocupó de temas económicos, políticos, jurídicos, religiosos y artísticos, y reunió a los filósofos, escritores y artistas revolucionarios y progresistas más importantes de la época. Desde 1936, la revista manifestó su solidaridad con la izquierda española, y en sus páginas eran frecuentes las reflexiones sobre la Guerra Civil española. Publicó los poemas de guerra y de temática revolucionaria de Rafael Alberti y Pablo Neruda, entre otros. El poema que deshonra al general Franco vio luz en el no 29 de Futuro, en julio de 1938 (Neruda, "El general Franco en los infiernos” 38), es decir, aún en plena Guerra Civil. El texto es, prácticamente, un poema de tono satírico que maldice y asocia el nombre de Franco con expresiones muy violentas, despectivas y ultrajantes: "Quién, quién eres, / oh miserable hoja de sal, oh perro de la tierra, / oh mal nacida palidez de sombra" (38). En la última parte del poema, Neruda maldice a Franco y le desea los sufrimientos más terribles del infierno: "Solo y maldito seas, / solo y despierto seas entre todos los muertos, / y que la sangre caiga en ti como la lluvia, / y que un agonizante río de ojos cortados / te resbale y recorra mirándote sin término" (38).

En los años de la Guerra Civil española, muchos poetas de la izquierda escribieron poemas de maldición contra Franco, entre los cuales el más conocido -junto con el de Neruda- es, quizás, el soneto de Antonio Machado ("A otro conde Don Julián”) en el que el poeta le desea la horca al general, aunque sin mencionar su nombre. La revista de Kassák publicó el poema de Neruda con diez años de atraso con respecto al nacimiento de la obra; sin embargo, el deseo del poeta chileno era aún actual, ya que Franco siguió en el poder en el país más allá de los Pirineos. La ineficacia de la maldición poética es bien sabida, ya que Franco murió de causas naturales en 1975, después de una dictadura que duró casi cuatro décadas.

El poeta José Herrera Petere luchó en la guerra española no solo con su propia poesía comprometida, sino también con armas, como voluntario en el famoso Quinto Regimiento. ${ }^{36}$ Después de la guerra emigró a México, desde donde se trasladó a Ginebra en 1947. En la emigración parisiense, en 1947, la unión de Intelectuales Españoles organizó una conferencia para conmemorar el aniversario cervantino -el cuarto centenario del nacimiento del autor de El Quijote-, evento en el que participó también José Herrera Petere. El poeta apenas vuelto a Europa desde la emigración americana leyó su poema "Invocación a Don Quijote". Casi al mismo tiempo, la revista Kortárs publicó la obra en

36 Un cuerpo militar de voluntarios de la Segunda República española durante los primeros meses de la Guerra Civil. Al Quinto Regimiento estuvieron alistados o relacionados con él poetas y escritores comunistas, por ejemplo, Rafael Alberti, Pedro Garfias, Miguel Hernández o María Teresa León. 
húngaro, en la traducción de Endre Gáspár (Herrera Petere 420). En el poema -que lleva el subtítulo "A la memoria del 14 de febrero de 1931, la proclamación de la República Española"-, el héroe de Cervantes simboliza todo lo español, y la lucha desigual de Don Quijote es identificada con la lucha de este pueblo. Las palabras estimulantes del poema se dirigen a los quijotes proletarios y los versos retumban la esperanza de la emigración republicana. Entonces, los intelectuales exiliados españoles aún vivían en la ilusión de que pudieran tener influencia sobre los acontecimientos de su patria.

Hemos mencionado ya al chileno Pablo Neruda a propósito de la publicación de un poema suyo en la revista Kortárs [Contemporáneo]. El nombre de su compatriota, la poeta Gabriela Mistral, aparece en otro número de la misma revista de Kassák, en una crítica no muy positiva de László András, con el título "Gabriela Mistral, la mediocridad sellada”. El filólogo hispanista y traductor literario reflexiona sobre el valor y el mensaje del Premio Nobel de Literatura a propósito de la concesión del famoso galardón ${ }^{37} \mathrm{y}$, en vez del elogio a la poeta chilena, expresa más bien su duda: "Hoy día, ¿el Premio Nobel de Literatura tiene el mismo valor que antes? ¿Podemos confiar ciegamente en su valor?” (285). László András, con su crítica sobre la poesía de Gabriela Mistral, nos da la respuesta: "el nivel de sus poemas apenas llega a la calidad de los poemas infantiles del tío Pósa. ${ }^{38}$ [...] Si Gabriela Mistral recibió el Premio Nobel, Lajos Pósa habría merecido igualmente este galardón importante" (285). En América Latina hay muchos que en talento adelantan a Mistral -escribe-, y menciona como ejemplos a Pablo Neruda, ${ }^{39}$ "el mayor poeta de habla hispana" (285), al cubano Nicolás Guillén, al ecuatoriano Jorge Icaza y al brasileño Jorge Amado. ¿Por qué, entonces, la decisión de la Real Academia Sueca? László András opina que en el fondo había motivos políticos, porque los mencionados poetas y escritores no callaron su opinión política ni en sus obras y, quizás, por eso no fueron galardonados con el premio literario. Su conclusión: "Parece que para que alguien pueda recibir el Premio Nobel, no debe reflejar sus ideas políticas en sus obras, o si lo hace, entonces su opinión sea como la de André Gide [...] que mereció el premio más bien por su toma de posición política bastante confusa”. Junto con Gabriela Mistral, conocida por "sus poemillas infantiles" (285), y André Guide, criticado por su opinión política aunque András no duda en el valor de su obra artística-, el hispanista húngaro pone también el ejemplo del suizo Hermann Hesse - "un escritor gris que no era partidario del progreso" (285) - para intentar demostrar cómo el Premio Nobel de Literatura perdió su antiguo esplendor y su valor original. ${ }^{40}$

37 Gabriela Mistral recibió el Premio Nobel en 1945. Entonces ¿por qué nació esta crítica en 1947, dos años más tarde? László András escribe que el motivo de la tardanza fue la guerra, ya que en el último año del conflicto los intelectuales se preocupaban por otras cosas.

38 Lajos Pósa (1883-1914), escritor y poeta, un clásico de la literatura infantil húngara. Publicó más de cincuenta poemarios con poesía para niños.

39 Pablo Neruda recibió el Premio Nobel mucho más tarde, en 1971.

40 El autor del artículo, László András no conocía toda la obra de Mistral (Desolación, Tala, Poema de Chile, textos políticos en prosa, etc.); así, en su crítica es notable una reducción enorme e injusta de la figura de la poeta chilena. 


\section{La revista Alkotás [Creación]}

La última revista que tenemos que mencionar es Alkotás [Creación], que no fue una empresa personal de Kassák; sin embargo, este tuvo un papel importante en su redacción. La revista nació de la iniciativa del Consejo de Arte Húngaro después de la Segunda Guerra Mundial, como órgano de la defensa de los intereses de los artistas húngaros, e integraba a escritores, artistas de bellas artes y de artes aplicadas, músicos, actores y cineastas. La publicación servía, en primer lugar, a la difusión de la cultura socialista ¿local?, pero con sus reproducciones en color tuvo un éxito considerable también en el extranjero. Visto que los escritores, los artistas de bellas artes y las artes aplicadas, los músicos y los cineastas organizaron sus propias asociaciones y fundaron también revistas autónomas, el Consejo de Arte Húngaro terminó su actividad. Por eso, la revista Alkotás no tuvo una vida muy larga, llegó solo a dieciséis números.

En su número doble 3-4 (1948), Alkotás publicó el poema “Grito hacia Roma” de Federico García Lorca en la traducción de László András ${ }^{41}$ (“Kiáltás Róma felé” 12). La poesía, rica en imágenes surrealistas, nació durante la estancia de García Lorca en América, apareció en el tomo póstumo Poeta en Nueva York y es -junto con los poemas “Crucifixión" y “Cementerio judío", nacidos también en los años 1929-1930- la prefiguración de la ola de odio racista y antisemita que amenazaría a Europa, y cuyo primer acto se desarrollaría justamente en España. En los poemas mencionados suena la voz del poeta que expresa su solidaridad con las víctimas. La muerte es un tema recurrente en la poesía de García Lorca -su presencia es constante en el Romancero gitano-, pero esta muerte, en el tomo neoyorquino, no aparece en contexto natural sino en un ambiente urbano. En estos poemas, García Lorca alza su voz en defensa de un grupo social, pero no lo hace como político, sino que grita desde la plataforma de los valores eternos de la humanidad. En la lucha entre la consciencia y el instinto, la servidumbre y la libertad, el poeta quiere defender lo que fue destruido por la civilización, ya que las emociones, las intuiciones, los instintos y el mundo natural son la base y la esencia de la poesía. Nueva York, para Lorca, es la ciudad de los números y de la colectividad. Casi no alude al individuo, sino que siempre evoca a grupos: el de los negros, de los niños, de los marineros o de los soldados. El carácter inhumano del trabajo lo destaca el poeta por medio del uso de números y nombres colectivos ("herreros", "niños", “carpinteros", "multitud”, "gentío"): "No hay más que un millón de herreros / forjando cadenas para los niños que han de venir. / No hay más que un millón de carpinteros / que hacen ataúdes sin cruz. / No hay más que un gentío de lamentos / que se abren las ropas en espera de la bala" (Poeta en Nueva York 263).

41 László András tradujo todas las obras en prosa publicadas en el segundo tomo de Obras completas de Federico García Lorca en húngaro (1967). También el teatro irrepresentable de Lorca y Los sonetos del amor podemos leerlos en húngaro gracias a su trabajo traductor (García Lorca, A közönség. Címtelen színdarab; A sötét szerelem szonettjei). 


\section{Ilustraciones de las revistas}

En las revistas fundadas por Kassák, junto a la literatura y a la política actual, podemos encontrar muchas fotografías, litografías y reproducciones de pinturas. Entre estas, se debe destacar una referencia española también: las obras de Pablo Picasso.

$\mathrm{Ma}[\mathrm{Hoy}]$ publicó cuatro reproducciones del pintor cubista: tres obras indicadas simplemente con el título Festmény [Pintura] (15 de septiembre de 1917, p. 173; 1 de julio de 1919, p. 197; 1 de enero de 1922, p. 21), y el cuadro Die erste Menager aus «La parade». Ballett von Jean Cocteau [El primer Menager de «La desfile». Ballet de Jean Cocteau] (15 de septiembre de 1924, p. 170).

Dokumentum [Documento], la revista de Kassák de vida más breve -llegó solo a su quinto número-, incluyó entre sus materiales visuales una sola pintura de Picasso, con el título Kép [Cuadro] (1927, n 3), pero en la revista Munka [Trabajo], de vida más duradera entre las publicaciones editadas por el líder del vanguardismo español, encontramos cuatro reproducciones: dos en portada (en 1936, no 52 y 57), una en el respaldo (en 1939, no 65) y otra en este mismo número, como ilustración junto al texto, en el interior de la revista (p. 2221).

Dos números de Kortárs [Contemporáneo], revista publicada en 1947-1948, también reprodujeron tres cuadros del pintor malagueño: dos ilustraciones a la novela La obra maestra desconocida de Balzac (n 1947-1948, p. 86-7) y la reproducción La escultora (no 1947-1948, p. 141).

Por último, en Alkotás [Creación], también hay dos obras de Picasso: la primera es la reproducción en color de un bodegón (n $1-2$ de 1947, p. 17) y un cuadro de escenografía (nº 7-8 de 1947, p. 45).

Además, la atracción de Kassák por el arte de Pablo Picasso se manifestó no solamente en la elección de las reproducciones arriba mencionadas como ilustraciones en las revistas, sino también de otra forma. El artista húngaro dedicó a su colega cubista importantes escritos: reseñas que analizan el arte de Picasso (Kassák, "Picasso"), salutaciones dedicadas a los cumpleaños del pintor - a sus sesenta y a sus setenta y cinco años (Kassák, "Picasso hatvan éves"; "A 75 éves Picassó köszöntése”) - e, incluso, un poema homenaje con el título "Pablo Picasso" (1977).

\section{Conclusión}

Lajos Kassák fue una de las personalidades más interesantes de la literatura húngara de la primera mitad del siglo xx. Fue un hombre multifacético: escritor, poeta, crítico literario y de bellas artes, periodista y fundador de revistas culturales. Precisamente con estas últimas jugó un papel pionero también en el nacimiento de la tipografía moderna en Hungría. Como líder de la vanguardia húngara, Lajos Kassák trabajó concienzudamente durante toda su vida para estrechar las relaciones entre los artistas 
húngaros y los representantes más destacados de los ismos artísticos de aquel periodo. Sus publicaciones contribuyeron a la difusión de las novedades de estas corrientes en el país centroeuropeo y, a la vez, se convirtieron en los foros más importantes tanto para artistas húngaros como para los internacionales. El constructivismo y el activismo fueron las tendencias más importantes que quería aclimatar en Hungría, pero también los ejemplos del expresionismo, el dadaísmo, el futurismo y el surrealismo despertaron su interés, y abrió sus revistas ante estas corrientes vanguardistas.

Su contacto con los círculos de artistas hispanos -tanto españoles como hispanoamericanos- no fue tan fuerte como su relación con artistas de Europa central y oriental (alemanes, franceses, polacos, rusos, etcétera), pero, como muestra el repaso de sus revistas, podemos constatar que Kassák sí que prestó atención a temas de actualidad y personalidades destacadas de la cultura española e hispanoamericana. Repasando las cinco revistas fundadas por él, hemos destacado tres líneas de temática hispana. En primer lugar, la política contemporánea de España (la dictadura de Primo de Rivera, la Segunda República y la Guerra Civil) despertó el interés de los periodistas húngaros. En segundo lugar, también la literatura recibió atención y publicidad a través de la publicación de las traducciones de algunos poemas representativos de los ismos de habla hispana (creacionismo y ultraísmo) y de ensayos de perfil literario. Por último, hemos mencionado el entusiasmo de Kassák por el arte cubista de Pablo Picasso, que se manifestó también en la selección del material visual de las revistas examinadas.

Aunque no forma parte integrante del análisis del presente artículo, hay que destacar también que el archivo del Museo Kassák de Budapest guarda una carpeta que contiene la correspondencia de Lajos Kassák desarrollada para realizar un proyecto que consistió en hacer una encuesta sobre el arte moderno. Su carta, después de una parte introductoria y explicativa, expone veintidós preguntas para los artistas entrevistados. La mayoría de los destinatarios fueron franceses; sin embargo, en la lista de Kassák aparecen también seis nombres de artistas hispanohablantes: los escritores Camilo José Cela y José María Castellet, los poetas Rafael Alberti, Nicolás Guillén y Pablo Neruda, y el violonchelista Pau Casals. El archivo guarda solamente las respuestas de Cela (tres hojas) y de Castellet (cuatro hojas). Con un análisis más profundo de esta encuesta -que es nuestro proyecto para el futuro- ampliaríamos y completaríamos también nuestra investigación desarrollada para averiguar las huellas hispanas en la obra de Lajos Kassák.

\section{Referencias}

András, László. “Gabriela Mistral, avagy a fémjelzett középszer”. Kortárs, s.n., 19471948, p. 285.

Borges, Jorge Luis. "Rusia”. Grecia, n 48, 1920 p. 7.

---. "Rusia”. Cosmópolis 23, 1920 pp. 485-486.

---. “Ultraísmo”. Nosotros, n 151, 1921, pp. 466-471. 
---. “Oroszország”. Ma, nº 9, 1921, p. 122.

Csaplár, Ferenc. Kassák körei. Budapest, Szépirodalmi Könyvkiadó, 1987.

Dauphin-Meunier, Achille. “A diákság és a spanyol forradalom”. Munka, nº 17, 1931, p. 471.

Falus, Ervin. "A spanyol forradalom mozgalmi kérdései”. Munka, n² 20, 1931, pp. 537-541.

Galambos, Ferenc. “Kassák Lajos folyóiratai”, s.l., s.f., http://mek.oszk.hu/12600/12647/12647. pdf. Visitado 24 de nov. de 2017.

García, Carlos. "Biografía de un poema de Borges: Rusia (1920)”. https://www.academia. edu/22437296/Biograf\%C3\%ADa_de_un_poema_de_Borges_Rusia_1920_. Web. 24 Nov. 2017.

García Lorca, Federico. Cigányrománcok. Budapest, Lux, 1947.

---. Cigányrománcok. Budapest, Cserépfalvi, 1947.

---. "Három spanyol románc”. Traducción de László András. Kortárs, s.n., 1947-1948, p. 76.

---. “Kiáltás Róma fele’”. Traducción de László András. Alkotás, n 3-4, 1948, p. 12.

---. Federico García Lorca válogatott müvei. Budapest, Európa Kiadó, 1963.

---. Federico García Lorca összes müvei, tomos I-II. Budapest, Helikon, 1967.

---. A közönség. Címtelen színdarab. Budapest, Helikon. 1981.

---. A sötét szerelem szonettjei. Budapest, Európa. 1988.

---. Poeta en Nueva York. Primera edición del original fijada y anotada por Andrew A. Anderson. Barcelona, Galaxia Gutenberg, 2013.

Gorkin, I. G. "Levél Madridból”. Munka, n 18, 1931, p. 491.

Haraszti, Zoltán. "Színházak”. A Tett [Budapest]. 15 Nov. 1915, p. 35.

Havas, Endre. “Dokumentumok”. Munka, n 48, 1936, pp. 1447-1453. Herrera Petere, José. “Ébresztődal Don Quijotéhez”. Traducción de Endre Gáspár. Kortárs, s.n., 1947-1948, p. 420.

Huidobro, Vicente. “Vers". Traducción de Sándor Barta. Ma, n 5-6, 1922, p. 14.

---. “Torony”. Traducción de Gyula Illyés. Ma, n 1, 1923, p. 98.

---. "Manifiestos: Non Serviam”. Obras completas. Santiago de Chile: Editorial Andrés Bello, 1976. https://icaadocs.mfah.org/icaadocs/THEARCHIVE/FullRecord/ tabid/88/doc/1126176/language/en-US/Default.aspx. Visitado 24 de nov. de 2017.

Katona, Eszter. Así que pasen 60 años: los dramas de Federico García Lorca en los teatros húngaros entre 1955 y 2015. Huelva, Universidad de Huelva, 2016.

---. “Kassák Lajos és a magyar avantgárd spanyolországi recepciója”. Tiszatáj, n 12 , 2017, pp. 140-153.

---. “España y temas hispanos en la obra literaria de Lajos Kassák”. Colindancias, n 8, 2017, en edición.

Kassák, Lajos. “Reflexiók”. Munka, n 52, 1936, pp. 1606-1612.

---. "Picasso hatvan éves". Magyar Nemzet [Budapest], 5 Nov. 1941.

---. “Picasso”, 1948. Archivo del Museo Kassák de Budapest, carpeta núm. KM-an., 485.

---. “A 75 éves Picassó köszöntése”, 1956. Archivo del Museo Kassák de Budapest, carpeta núm. KM-an., 459. 
---. “Pablo Picasso”. Összes versei, tomo II, Magvetö, Budapest, 1977, pp. 474-475.

Machado, Antonio. “A otro conde Don Julián”. Monique Alonso, Antonio Machado. Poeta en el exilio. Barcelona, Anthropos, 1985, pp. 85-86.

Menczel, Gabriella. "Előszó: A hispán avantgárd mozgalmak”. Non serviam. A spanyol nyelvterület avantgárd programszövegei. Eds. Gabriella Menczel y László Scholz. Budapest, ELTE, 2012, pp. 5-34.

Neruda, Pablo. "El general Franco en los infiernos". Futuro, n 29, 1938, p. 38.

---. "Franco tábornok a pokolban”. Traducción de Endre Gáspár. Kortárs, s.n., 19471948, p. 212.

Quintana, Emilio. "Primera traducción de Jorge Luis Borges al húngaro: el poema Oroszország (Rusia) publicado en MA (1921)”. Hallali. Revista de estudios culturales sobre la Gran Guerra y el mundo hispánico, n 4, 2010, s.p. http://www. revistahallali.com/2010/03/01/borges-ultraista-en-hungaro/

Quintana, Emilio y Jorge Mojarro Romero. “Tadeusz Peiper como traductor de la poesía ultraísta al polaco (1921-1922).” 1611 Revista de Historia de Traducción, n 3, 2009, s.p.,http://www.traduccionliteraria.org/1611/art/quintana-mojarro.htm\#n1

Quintana, Emilio y Ewa Palka. "Huidobro, Borges, Peiper y las primeras traducciones ultraístas al polaco (1922)." Cuadernos Hispanoamericanos, n 541-542, 1995, pp. 223-31.

Révész, Andrés. "El movimiento literario en Hungría”. Cosmópolis [Madrid], 6 Sept. 1919.

---. "Kassák y su Dokumentum”. La Gaceta Literaria, n² 21, 1927, p. 5.

---. "Kassák Lajos: Egy embre élete”. La Gaceta Literaria, n² 24, 1927, p. 4.

Rivas Panedas, Humberto. “Océano”. Ultra, n 12, 1921, p. 3.

---. “Océano”. Formiści [Cracovia], Mayo (1921), http://farm3.static.flickr. com/2028/2529594042_19297b9ce9_b.jpg. Visitado 24 de nov. de 2017.

---. “Amanecer". Ultra, nº 10, 1921, p. 3.

---. “Óceán”. Ma, nº 8, 1921, p. 102.

Ródenas de Moya, Domingo. Poética de las vanguardias históricas. Antología. Madrid, Clásico Marenostrum, 2007.

Sánchez Oms, Manuel. "La construcción poética, un legado de la vanguardia húngara (1915-1939)". Artigrama, n² 23, 2008, pp. 657-679.

Tihanyi, Lajos. "Vicente Huidobro". vv. AA. Lajos Kassák y la vanguardia húngara. Valencia, IVAM, Centre Julio González, 1999.

Tóth, Éva. Antología de la poesía húngara desde el siglo XIII hasta nuestros días. Budapest, Corvina, 1981.

Vajda, Imre. "Világpolitika”. Munka, n 12, 1930, pp. 359-360.

---. "Világpolitika”. Munka, n 13, 1930, p. 396.

vv. AA. Lajos Kassák y la vanguardia húngara. Valencia, IVAM Centre Julio González, 1999.

vv. AA. El cartel comercial moderno de Hungría 1924-1942. Madrid, Pentagraf-Beniparrell, 2009. 